\title{
Mario Vargas Llosa, The Fabulist of Queer Cleansing
}

Paul Allatson, University of Technology, Sydney ${ }^{1}$

“... one lies or distorts knowing that one is distorting" - Mario Vargas Llosa.

In 2005 Mario Vargas Llosa delivered his lecture, “Confessions of a Liberal,” for the Washington-based American Enterprise Institute for Public Policy Research. A summation of Vargas Llosa's intellectual evolution since the 1960s, the lecture confirmed his claim to the mantle of Latin American Liberal par excellence. Plotted in opposition to ideology as "an open, evolving doctrine that yields to reality instead of trying to force reality to do the yielding," Vargas Llosa's Liberalism rests on a number of familiar precepts: political democracy; private property; the free market; and the rule of law in productive tension with "the defense of individual interests over those of the state.” For Vargas Llosa, moreover, Liberalism also signifies "tolerance and respect for others, and especially for those who think differently from ourselves, who practice other customs and worship another god or who are non-believers,” hence his support for the "separation between church and state" and "the decriminalization of abortion and gay marriage.” Given Vargas Llosa’s shift from the left to the right of the political spectrum, and his well-publicized impatience with political agendas opposed to his own, the argumentation here was somewhat disingenuous. Equally disingenuous was Vargas Llosa’s celebration of a Liberal "natural lack of trust in power, in all powers." For there is one power that he does, in fact, trust: his own as a writer and as an "author-function,” to use Foucault’s term for an author's

\footnotetext{
${ }^{1}$ This chapter revisits and reworks my article "Historia de Mayta: A Fable of Queer Cleansing” (Revista de Estudios Hispánicos 32.3, 1998: 511-35). I am grateful to Steven Gregory and Diana Palaversich for their contributions to the earlier article, and Jeffrey Browitt for his inputs into this chapter.
} 
appearance and function in discourse.

Faith in that power has a long provenance in Vargas Llosa's oeuvre, but it appeared with a new confidence in his 1984 novel Historia de Mayta (1984), translated as The Real Life of Alejandro Mayta (1986). ${ }^{2}$ Historia, in fact, is a formative publication in Vargas Llosa’s literary and political development alike. It confirmed the author's antipathy for leftist political agendas (ideological lies, destructive fictions), and it announced that such displeasure would henceforth color his authorial concerns (literary truths, productive fictions). Vargas Llosa noted as much in his essay, “Transforming a Lie into Truth: The Real Life of Alejandro Mayta as a Metaphor for the Writer’s Task”:

Ideological fiction is what Mayta and his comrades live.... On the other hand Historia de Mayta is a description of the other kind of fiction, a fiction that the narrator/writer is trying to write. The reader sees in the novel how this other fiction, which is also an imaginary construction that has some roots in reality, as in the case of this ideological fiction built by Mayta, does not have these negative or even catastrophic results but has positive ones because at least in this world, which is going to pieces, which is practically disappearing in an orgy of violence, this man who is writing finds a reason to resist, to live. (A Writer's Reality 153)

Historia de Mayta, moreover, serves Vargas Llosa as a key literary template for his post-1984 career: "The story of Mayta, then, is my own story of a writer writing his fiction. What the narrator does with Mayta is what I do each time I write a novel” (155).

But what does the narrator, and the novel's author-function-its textual stand-in for the realworld writer-do with Mayta? Toward the end of Historia, after the narrator has travelled across Peru in search of his subject, he finally meets the "real” Mayta. After telling this Mayta of his

\footnotetext{
${ }^{2}$ Page references in this chapter come from The Real Life of Alejandro Mayta.
} 
research for the book he is writing, he says: “The character in my novel is queer” (301). Mayta’s incredulous "Why?” elicits the following reply: “To accentuate his marginality, his being a man full of contradictions. Also to show the prejudices that exist with regard to this subject among those who supposedly want to liberate society from its defects. Well, I don't really know exactly why he is” (301). The “real” Mayta’s response to this explanation creates a breach between the Mayta or Maytas learned about up to that point and the person finally tracked down and allowed to speak. And when that Mayta says “They say Mao shot all the queers in China” (301), he has the final word on the novel's queer presence.

Why then, and with what implications, is Mayta, or one version of him, queer? In the critical literature about Vargas Llosa's fictionalization of a specific moment in Peruvian history, the novel's complex figuration of homosexuality has not attracted sustained attention. ${ }^{3}$ My interest, aroused in part by that critical oversight, lies in plotting the gradual revelation of one historically situated body signed queer in relation to the novel's figurations of a Peru conceived of as an ailing body politic, within a third body, the text itself. For it is in the structure of a fictionalized history held together by the investigations and inventions of the elusive narrator that the other two bodies are displayed. Somewhere in the convergence of these three bodies lies the answer to the "real” Mayta’s, and my own, why? In responding to those questions, my analysis regards Historia as a doubly important textual moment in Vargas Llosa’s post-1984 Liberal and writerly career. First, the novel begins to indicate the extent to which Vargas Llosa’s political and philosophical embrace of Liberalism is haunted by the figuration of queerness. Second, Historia

\footnotetext{
${ }^{3}$ Most attention has been paid to two areas: Vargas Llosa's problematization of history, his contamination of notions of truth, objectivity and fact by constructing history with the same inescapable lies as are employed in fiction; and his (mis)treatment of the Peruvian left. See, for example, Newman, Reisz de Rivarola, Chrzanowski, de Grandis, and Muñoz.
} 
confirms that the limits of Vargas Llosa's Liberalism are reached in that figuration.

\section{Diagnosing Peru}

Historia de Mayta opens and closes with images of Lima, but the pleasant ambience through which the narrator runs in the first paragraph will not reappear in the novel: "because everything man-made there is ugly” (3). If that brief sentence serves as an initial diagnosis, the following paragraph describes the city’s symptoms. Beset by urban decay Lima is ugly, fearful and suffocating. Poverty and misery have spread and are all encompassing, touching even wealthy and privileged districts. Lima is now a garbage dump, and dogs and people swarm across it like maggots on carrion. At the novel's end, the narrator again passes through the evocative wasteland, thinking of epidemics, wounds, and premature deaths. The narrative thus ends with a return to the diseased present, in which invading garbage, people and epidemics imply that there is no hope of recovery for the patient: “And I'll remember that a year ago I began to concoct this story the same way I'm ending it, by speaking about the garbage that's invading every neighbourhood in the capital of Peru” (310). The patient in this novel is Peru, as the Warden in the last chapter iterates: “The whole country’s the problem” (283).

The Peru through which the narrator moves as he gathers testimonies belongs to a present that is also an unspecified, fictionalized future of a Peru outside the text. The present/future Peru contrasts with the reconstruction of events from Peru in 1958. Although the narrator's researches are being written twenty-five years later, the futuristic aspect of the present is reinforced by the description of a country at war, invaded by Cuban and Bolivian troops, and against which are arraigned the governing junta's armed forces and supporting U.S. troops. Temporally, the novel charts an inexorable decline in the health of Peru from the late 1950s to the moribundity of the 
narrator's present/future. In chapter three, for instance, the narrator describes his Dantean impression of crossing the circles of hell as he drives from Lima's centre to the outlying slums. The trip evokes the decline of the city from the unremarkable poverty of the past to a present dominated by overwhelming poverty and violence. The fearful psychic and physical effects of the environment are quite palpable as the narrator waves his arms at flies, as if the filth of the slums, and the apparent lethargy and expressionless of their inhabitants, were infectious.

Such images of a terminally ill Peru by no means represent a novel Vargas Llosian invention in Historia. They also figure in Vargas Llosa’s other fictions, an infamous example being “'En qué momento se había jodido el Perú?” (I, 13) (“At what moment did Peru become fucked?) on the first page of Conversación en la catedral (1969). Moreover, the trope has appeared with startling regularity in Peruvian letters since Manuel González Prada, whose writings, from the 1880s on, are rich in exemplary aphorisms: "El Perú es como esos enfermos desahuciados por los médicos" (Perus is like those patients the doctors claim are beyond recovery” (196); "En el organismo político, ninguna enfermedad produce mayor estrago que el oportunismo progresivo” (In the political organism, no disease produces more degeneration than progressive opportunism) (210); and "El Perú es un organismo enfermo: donde se aplica el dedo brota al pus" (Peru is a sick organism: when one applies a finger out oozes pus) (qtd. in Mariátegui 204). If these aphorisms foretell Vargas Llosa’s diagnoses of the Peruvian malaise, González Prada’s aims, and the context in which he wrote, were very different. According to Higgins, González Prada’s targets were specific Spanish colonial and neocolonial state apparatuses:

Spain had bequeathed a sorry legacy of venality, corruption and intellectual obscurantism which had turned Peru into a sick organism, he argued, and the nation would never be made healthy till the oligarchy, the Church, the military and all the other institutions of the past 
were destroyed, till Lima's stranglehold on the country was broken, and till the mestizo proletariat and the Indian peasantry were freed from their servitude and their servility. (7273)

Higgins also notes how images of the sick Peruvian body were common in writings from the 1950s and 1960s, including Eduardo Congrains Martín’s deromanticizing novel, No una, sino muchas muertes (1957), and Sebastián Salazar Bondy’s Lima la horrible (1964) (192-93). Moreover, the idea of the ailing nation, indeed, of the infirm continent, has a long provenance among Latin American intellectuals, from the Argentinian Sarmiento and the Bolivian Alcides Arguedas to the Puerto Rican Pedreira, all of whom linked national pathologies to racial ones (Franco 55-61; Flores 19, 33). Historia thus has a discursive relation to long-standing, yet unresolved, Peruvian, regional and continental debates concerning what José Carlos Mariátegui called the “Indian problem,” although writers such as Mariátegui and José María Arguedas sought to disprove the equation that indigenous Peru equalled diseased Peru. ${ }^{4}$

In Historia that equation persists, nonetheless, to underwrite the depictions of Lima, and by extension, of the country. Visiting Vallejos’s sister Juanita, a nun working in the Liman slums, the narrator reports Juanita's views on her order's early attempts at combating poverty, by tending to the education of the rich (the head) who, in turn, will care for, and improve, the status of the poor (the body). Such attempts failed to change the world, as Juanita admits. The implication is that the nation is subject to an entrenched disease, hence the vast array of opportunistic infections from which it is suffering. ${ }^{5}$ Lima is host to numerous physiological ills. In its leprous street corners, sordid convents and squalid cantinas swarm the human parallels to

\footnotetext{
${ }^{4}$ Latin America's post-1945 rightwing dictatorships also conceived the ideological enemy-within as a cancer to be excised if national health was to be saved. My thanks to Diana Palaversich for reminding me of this connection.

${ }^{5}$ The passage also allows the narrator to allude to and dismiss liberation theology as a potential force of change in the Perus constructed in the novel.
} 
the city’s inanimate pollution, Indian migrants from the Andean provinces comprising the greatest number. These are, as the narrator puts it, the “cancerous growth” on Lima's buses (119, 105), the beggars who "constitute a sort of grotesque royal court of tatters, grime, and scabs" (109), and the slum-dwellers living in fetid garbage dumps. The narrator's impression of not being in Lima, but rather in an Andean village, makes synonyms of Indians and basuras. These connections support Guzman’s view that “poverty ... is important in this book mainly by its incidence in the condition of bodies” (138). But, while the Peru in Historia de Mayta is figured as diseased corporeality, it is also pointedly a racialized, indigenous corporeality. ${ }^{6}$

In Historia's descriptions of Lima, then, two temporal Perus (past and present), and two classdefined Perus (rich and poor), are explicitly related to two disparate Spanish and Quechua Perus. The divide between Spanish and Indian Perus, moreover, is linked to yet more Perus, the capital and the Andean provinces. ${ }^{7}$ In this respect, it is significant that the narrator's investigations enable him to extend his national diagnosis by tracing the moribund effects of the capital on all of Peru's parts, including the Andean terrains of Indian Peru. This is exemplified by the narrator's responses to Jauja, the former capital and site of Mayta's planned revolution, described in terms of past greatness and a decline attributed to the energy-sapping power of Lima. Jauja was also once the destination for people with tuberculosis, its reputation as a sanatorium, according to the narrator, mythologized in literary texts and by romantic sadomasochists. But now it only signifies “perforated lungs, fits of coughing, bloody sputum, hemorrhage, death from consumption” (117).

\footnotetext{
${ }^{6}$ It is worth noting that Vargas Llosa's pitting of Spanish/European against Indian does not provide space for mestizo Peru to emerge in the Peruvian realities dealt with in the novel. This suggests a view of the "Indian problem" that is conceptually and ethically antithetical to the work of Arguedas, for example in his Formación de una cultura nacional indoamericana. See Spitta for a nuanced discussion of Arguedas's ideas, and Rowe for an astute argument that Vargas Llosa has consistently misread Arguedas's intellectual position.

${ }^{7}$ Vargas Llosa also elaborated on this host of antagonistic Perus in "Discovering a Method for Writing" (Writer's Reality 41-42).
} 
The city's past reputation, then, is as prone to new pathologized significations as Lima. And lest this example fail to remind the reader that the provinces have not been immune to the contagions afflicting Lima, the narrator later reinforces his impressions of “dirt as disorder” (Douglas 2) with the following imagined conversation:

Yes, Mayta, millions of Peruvians lived in this same grime, in this same abandonment, amid their own grime and excrement, without light or water, living the same vegetable life, the same animal routine [as ...] this woman ... with whom ... he hadn't been able to exchange more than a few words, because she barely knew any Spanish. (254)

Peru has been subject to an inexorable contamination of which there are few differences, except in degree, between the conditions that Mayta is reported to be witnessing and those the narrator encounters twenty-five years later.

The incipient nature of this national indisposition, directly linked here to the racial, linguistic and economic gulf between “civilized,” non-Indian Spanish speaker and “primitive,” non-Spanish speaking Indian, suggests that the national syndrome not only targets high risk and marginalized groups, but originates with, and is spread by, them. In the novel, then, the viral metaphor used to apportion blame reveals a peculiarly Peruvian crisis in signification of epidemic proportions, to rework Treichler’s description of AIDS discourses (32) in an era defined by an illness, coincidentally enough, whose spread into bodies and international consciousness is coterminous with both the present/future in the novel, and Vargas Llosa's writing of it.

In keeping with the pathogenic tropes deployed to describe the infirm national body and its inhabitants, the narrator utilizes similar metaphors in his investigation into the ideological sources of infection, which have long historical roots in Peru: "Violence of all kinds: moral, 
physical, fanatical, intransigent, ideological, corrupt, stupid—all of which have gone hand in hand with power here. And that other violence-dirty, low, vengeful, vested and selfish—which lives off the other kinds” (109). With such pronouncements, the narrator insinuates himself into the novel as somehow beyond, and therefore uninfected by, his pathologized surroundings. Yet, the specific political targets of his investigations suggest an undeclared ideological position on his part. In fact, the narrator's ideological interestedness is implied in his claims that a leftist parasite, genetically programmed for self-interest, feeds on the nation for its own ends. This diagnostics is reinforced by the play of a host of conflict-ridden binaries that are embedded in the many Perus displayed in the novel: First/Third world, capital/provinces, rich/poor, bourgeois/peasant, European/Indian, Spanish/Quechua, civilized/primitive, right/left, internal/external, normal/abnormal, fact/fiction, private/public, clean/contaminated and, of course, health/sickness. One effect of such ordering principles is that leftist ideologies in the novel are defined as at once impotent cures and powerful contaminants.

For the narrator and the Vargas Llosian author-function alike, the moribundity of Peru, its figuration as an epidemical disaster zone with no immuno-defense system, has an identifiable, and blameworthy, source of dystopian contamination. Speaking of Historia, Vargas Llosa is explicit about Peru’s particular pathogenesis:

these sometimes elaborate and complex ideological constructions in which one society was described and then another ideal society was also described as a goal to be reached through revolution, as well as a methodology of the way this revolution could be achieved, were, in fact, a mechanism that was destroying our societies and creating major obstacles to real progress and the battle against the things the revolution opposes—social injustice, economic inequalities, lack of integration of the different cultures. (Writer's Reality 150)

Indeed, because transmission of the viral ideology afflicting Peru is traced in the novel to a 
faction-ridden, insurgent left, the link between violence and infection has serious implications. As Sontag argues, the war metaphor often used to describe disease "implements the way particularly dreaded diseases are envisaged as an alien 'other,' as enemies are in modern war; and the move from the demonization of the illness to the attribution of fault to the patient is an inevitable one, no matter if patients are thought of as victims” (97).

\section{The pathologization of Mayta's body}

The pathologized metaphors used to describe Peru provide the discursive territories in which Mayta's body, and the conflicting historias concerning what he does with his body, are revealed. Those territories and historias confirm a particularly Peruvian version of a phenomenon that Sander Gilman has described with regard to western cultures:

[There is a] relationship between ideas of national space and ideas of race, between representations of the body and concepts of difference. These concepts are, of course, 'Western' and make use of the basic paradigms of 'race,' of 'difference,' of the 'normal' and the 'pathological' which are to be found in other 'Western' (read: Christian and/or scientific) cultures (not all of them in Europe and North America). (176)

However, Peruvian manifestations of this relationship between, on the one hand, national and racial ideals, and on the other, bodily representations, have been downplayed in the critical responses to the novel that concentrate on the depiction of Mayta as a revolutionary Trotskyite within Peruvian national space.

Dunkerley, for example, has astutely observed that Mayta’s “essential character is established by the only constant feature of the text: the understanding that the being of the left is singularly selfdetermined and, even more importantly, that the catastrophe that is contemporary Peru is 
centrally attributable to the agency of this left” (140). And yet, Dunkerley’s allusion to Mayta's “sympathetically” rendered private life glosses over the intimate convergence in the novel between the diseased national body and the body of Mayta, failed revolutionary and queer subject. For Souza, Mayta's homosexuality can be read as a parody of the concept that socialism represents the feminization of society, a claim that accepts as synonymous homosexuality and (ef)femenization.

Neither Souza, nor Dunkerley, interrogate the extensive deployment in Historia of discourses that simultaneously target the homosexual and the political left, not to mention the Indian. Mayta can only satisfy the synecdochal tag if his sexuality is regarded as abject and pathological by the narrator, and by the novel's readers. He must be seen to bear an identifiable and ultimately incurable, internal sickness that, in turn, parallels and further discredits the leftist and indigenous ills besetting Peru. That link has been made, albeit in passing, by Zapata, for whom from the novel’s opening, and its descriptions of Mayta’s ugliness, grotesqueness, incapacity for selfreflection and homosexuality, indicate his inevitable failure (193-94). Clearly, considering the novel's tropology of Peru's ill health and its overt identification of the ideological source of transmission, the convergence of Mayta’s political and sexual lives suggests that his symbolic role cannot be explained simply as either an ideological or a national synecdoche. Mayta’s textual function will be understood only partially if his negativized sexualization is not acknowledged and confronted. ${ }^{8}$

\footnotetext{
${ }^{8}$ Caro and Booker are among the few critics to note the negative treatment of homosexuality in Historia. This critical neglect is surprising, given that what Ellis calls "talk of homosexuals" forms a narratorial thread throughout Vargas Llosa's writing. Ellis regards such talk as “a concerted effort to publicly affirm a heterosexual identity” (78) on the part of the author. Browitt notes that Vargas Llosa's "portrayal of homosexuality and the working out of Oedipal complexes ... are worthy of a book-length study in themselves,” for they imply "a deeper attachment to heterosexual male machismo on the writer's part than perhaps Vargas Llosa realises or would care to admit” (132).
} 
From his first appearance, everything about Mayta points to the truth of the later description of him as a complete orphan. At the beginning of Historia Mayta is an empty signifier, a non-being, a corporeal space that requires fleshing out and a history. The narrator is determined to fulfil that requirement, however contradictory the results of his investigation-cum-reconstruction. He thus poses a series of unanswerable, but rhetorically telling, questions about his subject:

Because his case was the first in a series that would typify the period? Because he was the most absurd? Because he was the most tragic? Because his person and his story hold something ineffably moving, something that, over and beyond its political and moral implications, is like an X-ray of Peruvian misfortune? (15)

As the last question intimates, the political and moral essences of Mayta's persona signify a twosided identity requiring both exposure and diagnosis. To this split identity adhere descriptions of a sorry physical appearance, and other indicators of his marginality. The first description of Mayta, a fat child with flat feet, gaps between his teeth, and an ungainly manner of walking, reveals his physical ludicrousness. Furthermore, Mayta is the only school child with an Indian name, a Quechua word that signifies to roam aimlessly or without knowing one’s direction (Souza 173). Most significantly, the name indicates a cultural and racial positioning that unambiguously links Mayta, despite his ignorance of Indian cultures, to the novel's traffic in images of Indian squalor.

Up to the fourth chapter, the gathering of information about Mayta is framed by juxtapositions between sensualization and political rigour, by pointed questions, and by words and phrases (rumors, insinuations, gossip, secrets) chosen for their undermining suggestiveness and capacities to indicate Mayta's repressed ontological condition. The narrator's investigation thus focuses on the oppositions between public and private, and between secrecy and disclosure, that hover 
around the emerging Mayta. While it is clear that much of Mayta's secrecy can be attributed to an underground Trotskyite party that demands discretion of its members, the continual contrasts between political and moral secrecy also prepare the narratorial ground for the revelation of Mayta's homosexuality in the fourth chapter. The signs of Mayta's particular sexual interests, however, have always been present. They are hinted at in the first chapter with the narrator's questions about whether the friendship between Vallejos and Mayta was based on a political alliance, or, like love, signalled a deeper affinity formed at first sight. The insinuations continue with Vallejos’s confession that he has been teaching Marxism to a group of boys in the mountains, and Mayta’s response that such "bad” matters should not be spoken about. Most suggestive of all, Mayta’s “trembling” desires, kindled by his excitement at impending revolutionary action, begin to exceed the boundaries of political fraternity when he imagines the women who must have tasted Alférez’s well-defined lips and enjoyed his hard body.

Mayta is closeted, present but hidden, an open secret. The use of closetedness here is not intended as an anachronistic imposition of a post-1960s liberal concept of gay identity onto the novel's late 1950s frame. Rather it is to suggest that the western closet trope, by which homosexuals are conventionally revealed, concealed and potentially "liberated" as sexual identities, is at work in the narrative, and in the narrator's investigation of his subject. As Miller argues, the logic of the discourse of sexuality signposted by the closet, and its correlate coming out, highlights the policed production of identities in "the private and domestic sphere on which the very identity of the liberal subject depends” (ix). The open secret of Mayta requires reader familiarity with the closet trope in Historia as Mayta’s sexual essence is at once concealed and exposed to diagnostic scrutiny. Mayta, then, is doubly closeted: anxiety-laden secrecy applies to his political allegiances and his homoerotic desires alike. Both can be interpreted in terms of a stigmatizing behavioural 
passivity unfitting for a machista, or better said, a machista leftist, and of a concealed but essential sexual identity core as understood in post-1960s gay liberation terms. Mayta’s open secret thus impels “journalistic scrutiny and exposure,” and makes him into a doubly troubling sign "of inauthenticity and of a difference all the more subversive because [it is] simultaneously threatening ... and potentially unidentifiable” (Edelman 152). ${ }^{9}$

The fourth chapter confirms the implied links between Mayta's political and sexual inclinations made up to that point. As the narrator records the testimony of Senator Anatolio Campos, he also constructs a revolutionary and sexual relationship between Mayta and the youthful Anatolio. These personal revelations occur in a chapter in which the futuristic parameters of the narrator's fictionalized present are also detailed. Apocalyptic war and the invasion of foreign troops meet political treachery, duplicity, factional conflicts and guilt among the left of an earlier era, these narrative threads intertwining with the first description of a sexual act between Mayta and Anatolio. The threads infect each other in a dense play of contrasting significations. For example, a description of a smiling Mayta, his body tense with anticipation, is followed by the narrator's loaded commentary ("The self-sacrificing Mayta transformed into a two-faced monster, weaving a really risky plot just to trap his comrades?” [89]). Introduced in the same insinuating language used to describe his political activities, Mayta’s subsequent request to Anatolio— “ “'Let me jerk you off,' he whispered in an agonizing voice, feeling that his whole body was burning” (95)_ adds weight to the implied link between political and homosexual recruitment.

\footnotetext{
9 A key depiction of another closeted homosexual occurs in Vargas Llosa's Conversación en la Catedral; the revelation of Don Fermín's hidden homosexual condition (II, 245-53) functions as a destabilizing literary device that, like Mayta, reveals and confirms the unhealthy truth of the ailing nation. Don Fermín's homosexuality is inextricably linked to the notion of a fucked Peru cited on the novel's first page (Pope).
} 
In this respect, the ensuing conversation between the senator and the narrator about the deceptions practised by so-called inverts is particularly telling. In that conversation, the senator defines the typical homosexual, and hence Mayta, as an incomplete feminized being, prone to treachery, and a discredit to the fixed and true sex allocated at birth. The definition reflects the conflation of a leftist dismissal of homosexuality as bourgeois decadence with the conventional machista view of sexuality as conforming to an active/passive matrix, one in which the full weight of hypermale opprobium is directed at the passive, and hence inferior, partner, in sexual acts. ${ }^{10}$ For the narrator, Anatolio has reasons of his own to emphasize the distinction between sexual passivity and activity. Mayta belongs to the former category. The demonization of a passive, feminized Mayta signifies the senator's desire to preserve untarnished his own macho reputation: he has always been on top, his masculinity unquestionable. At the same time, the narrator wants to discredit the senator's testimony by interlacing it with his own reconstructions of a pre-senatorial dalliance with Mayta, thereby indicating the senator's hypocrisy.

Neither the senator's demonization nor the narrator's construction of Mayta as queer, however, can be isolated from the narrative strands in which Mayta is accused of being a political traitor. Furthermore, sexual and political accusations are connected, because of proximity on the page, to the powerfully rendered descriptions of a national apocalypse. It thus becomes impossible to extract a non-abject Mayta from the narrative. In the narrator's account, Mayta emerges from his encounter with an accusatory Anatolio as a sad picture of internalized self-hatred, admitting to shame, and imagining himself purged of his contaminating desires. Mayta's supposed self image, and the senator's self-preservatory image of him is, as would perhaps be expected of the 1950s,

\footnotetext{
${ }^{10}$ For elaborations of this bodily economy, see Allatson.
} 
cast as a pathological condition, one reinforced by the narrator's third person description of Mayta's weakened physical state, just before Anatolio permits Mayta to give him a handjob. The incident, followed by the fusing of the narrator's and the imagined Mayta’s reactions to a posited national preoccupation with violence in the Museum of the Inquisition, confirm Mayta as a paranoic space in and on which are conjoined "the form of knowledge that represents at the same time 'knowledge itself' and a diagnostic pathology of cognition, or the cognition of a diagnosable pathology” (Sedgwick 97). Secrecy, disguise, dissembling, intrigue, treachery, invasion, entrapment, seduction, confession, shame, filth, anxiety, alienation, infection and disease: all converge in this chapter to characterize the entrance of Mayta's homosexualized body in the text.

\section{The maricón in gothic Peru}

After the fourth and pivotal chapter, the interplay between Mayta's erotic life and his revolutionary ambitions continues to overdetermine his novelistic existence as a pathologized being in a pathologized environment. In this respect, it is significant that in chapter five, Jauja is the setting for Mayta to be immobilised by altitude sickness that makes him resemble one of the city’s former tubercular patients. Under the influence of that sickness, Mayta is reported as wondering what sort of country Peru is, given that the mere movement from one region to another changes him into a "gringo, en marciano” (143) (a gringo, a Martian). Already othered as a “maricón,” the "marciano” Mayta becomes a native-born alien-within, the alarming patient zero who presages the foreign soldiers and other woes that later overrun the body politic.

Chapter five also details the expulsion of Mayta from his party for treachery, an accusation that encompasses both sexual and political perversion. The link is emphasized by the reported thoughts of Mayta himself at the imminent prospects of revolution as he recalls his night with 
Anatolio: "he had had in his arms the boy he had desired for so many years. He had made him experience pleasure and he had experienced pleasure himself. He had heard him whimper under his caresses” (142). For Comrade Joaquín in chapter six, however, the problem presented by Mayta is clear: how can an invert be a revolutionary? The narrator's commentary, interlaced with Mayta's purported thoughts, supposedly emphasizes the petty and confused prejudices that motivate the expulsion of Mayta from the party, not for lack of discipline, error, or treachery, but “for having slid his tongue, like a stiletto, between Anatolio’s teeth” (177).

And yet, in a chapter also concerned with the unforseen consequences of accidents, rumours and new knowledge, the narrator's asides betray a more insidious ulteriority behind the chapter's homosexual characterization. At one point during his conversation with Blacquer, the narrator isolates what he finds likeable about one Mayta — the older revolutionary who rediscovers his youthful vigor and throws himself into the cause-who has emerged in his research. He then follows this with an analysis of what was wrong with his subject:

If he had been able to control his sentiments and instincts, he wouldn't have led the double life he led, he wouldn't have had to deal with the intrinsic split between being, by day, a clandestine militant totally given over to the task of changing the world, and, by night, a pervert on the prowl for faggots. (166)

The word apestado here is highly charged. Mayta's pestilencial twilight sexuality is causally linked to both his revolutionary failure, and the epidemics of violence, terror, poverty and indigenous backwardness that the narrator blames for the destruction of Peru. In short, Mayta's homosexuality becomes a pathogenic signifier. Mayta’s shadowy and health-threatening activities situate him in, and as, to use Williamson's formulation, a "morass of unthinkability" in "a Gothic territory where fears are flung out into a sort of mental wasteland beyond the castle 
walls of the [narrator's/author's?] ego” (70).

An indisputably Gothic territory, in the form of a narrative strand detailing the massacres perpetuated by the invading Chilean army in 1881, shadows the descriptions of the narrator's meeting with Mayta's former wife in the seventh chapter. Adelaida is perhaps the novel's only true synecdoche of a Peru conceived as victim. She could also be read as a synecdoche of the novel itself, the literal screen—_pantalla,” in the original Spanish (214)—on which Mayta dissimulated his political and sexual li(v)es. Adelaida’s account of her discovery of Mayta’s homosexuality, one that made her retch, is caught in the narrative between images of contemporary apocalyptic progress and the epidemiological consequences of the Chilean invasion, as infections spread from the many unburied dead. Yet Mayta’s revolutionary aim to cure the diseased body politic is deflated by his wife's suggestion that he, not Peru, requires medical treatment. At the same time, descriptions of violent social change, of smoking ruins and pestilence, undercut Mayta’s utopian dreams for a revolution so that Peru will no longer be a rotten society, a revolution that will also be for the country's queers.

Mayta’s self definition in this chapter as a “maricón,” his avowals that he does not want to stop being one, and his utopian dream of a revolution for homosexuals, suggest an epistemological understanding of sexual identity unalike the passive betrayer of masculine behavioural conventions already noted. Mayta’s dream suggests, again, an internationalist concept of gay identity and liberation, an unlikely intrusion of a post-1960s liberal sexual utopic into the novel's late 1950s frame that serves to fix Mayta within a "morass of unthinkability” (Williamson 70). The conflicting models beg the question: how many homosexuals can Mayta signify? The answer is legion, for in chapter eight, Mayta the revolutionary is also insinuated into a deviant position as 
corruptor of minors. The at-risk group represented by the Josefinos is taken in by the erotic charge emanating from Mayta's game of revolution. As one school boy describes it, the experience was like losing his virginity. Mayta in this chapter is also impugned as the sensualist who lacks control and discretion, and as the aging revolutionary who regresses to a teenage realm when he rubs his gun against his fly. The image of Mayta as a homo-sensualized revolutionary thus undermines his pretensions to collective selflessness and self-discipline. The following chapter, which details the failure of the revolution, continues to link Mayta's lack of control or vigour, both leftist and sexual, with images of expelled body wastes, Indian squalor, and disabling altitude sickness. Mayta’s body now metaphorizes the narrator's insinuations of the left's inability to comprehend Andean conditions. Physical weakness, political ineptness, sexual inaptness, disease, filth, poverty, Indian abjecthood, the sinister landscape, and more apocalyptic rumours frame the penultimate chapter's characterization of Mayta: sad, defeated, imagining Anatolio’s head on his chest. Then, the chapter ends with the narrator's sudden, destabilising aside that the story told so far has been a lie, akin to fiction.

\section{Excising the maricón}

Lies and fiction, truth and reality, past and present, history and invention: as these binaries play through the text, producing competing knowledges about Mayta, the reader turns to the final chapter nonetheless assuming that this participant in a failed, if not farcical, revolution is also queer. His politicized and sexualized identities alike have been implicated in the processes that have destroyed the health of the nation. Mayta enters the novel's final pages as the symbolic and literal agent responsible for Peru’s decline. But, the narrator’s encounter with the real Mayta enacts a breach in the knowledge of Mayta accrued by the reader up to this point in the novel. The queer Mayta is a narratorial invention. As it turns out, the only significant revolutionary 
achievements of the real Mayta - the one speaking to the narrator in the final chapter-have been to establish a coupon system and to lobby for better standards of hygiene in prison. As for being queer, the idea is rejected by this Mayta, now figured as a homophobic paradigm of Latin American leftism:

I was never prejudiced about anything ... But, about fags, I think I am prejudiced. After seeing them.... Tweezing their eyebrows, curling their eyelashes with burned matches, using lipstick, wearing skirts, creating hairdos, letting themselves be exploited the same way prostitutes are exploited by pimps. How can you not be sick to your stomach? (301)

The real Mayta is a good family man, machista, and leftist. This Mayta has the final word, uttered between gritted teeth, on the homosexual presence in the novel: “They say Mao shot all the queers in China” (301).

According to Huston, in the interplay between truth and lies, Mayta becomes the text's only “autonomous and compelling lie,” an achievement that "creates the book, and which brings the real Mayta to judgement, convicts him of the sin of resignation” (116). The success of the novel for Huston, then, lies in its “revolutionary storytelling," by which "Vargas Llosa discovers not the real life of Alejandro Mayta, but his truer and more necessary fictional life” (117). Yet, whether or not the final chapter's Mayta can be read as the real one, in his final appearance this Mayta has been given an unambiguous role: he becomes the mouthpiece by which the queer subject is excised from the narrative. That excision is not simply explicable as a laying bare of the lie of either leftist ideology, or the deceptive devices employed in historical or fictional narration alike. In the novel, such devices and lies have made great use of the homosexual as an abject device. Indeed, that abjection is reiterated in the novel's final chapter in a brief passage before the moment of fabulous surgery. Here, the narrator details the lay out and appearance of 
Lurigancho prison. ${ }^{11}$ The prison, like the national body politic, is a congested, garbage-swamped, chaotic space populated by the mad and the violent, with a special section reserved for los maricas (fags) to prevent fights and rapes. Moving in that space, the narrator recalls asking a prison doctor about the effects of rape among the inmates. He receives this response: “"The most common problem is infections of the rectum, complicated by gangrene or cancer.' I ask Carrillo if there are still as many rapes. He laughs: 'It's inevitable, with people who have nothing else, don't you think? They have to let go somehow'” (285).

In a text congested with pathologized bodies, but only one queer body, that body cannot dodge the taint of, to cite the original Spanish, "el recto supurando, gangrenado, cancerizado" (318). This sodomitically charged image, casually placed in the novel's end pages, evokes what Edelman has called "the scene of the voiding of waste" as it "gets entangled in the national imaginary with a fantasy of cultural and historical vastation.” For Edelman, that fantasy "bespeaks a narcissistic anxiety about the definition of (sexual) identity that can only be stabilized and protected by a process of elimination or casting out” (168-69). Extrapolating that insight to Historia, and therefore to a Peruvian national imaginary, the final chapter confirms what the entire novel has insinuated: the novel's most vital excrescence is the queer, signified throughout the text as a pathogen responsible for transmitting a deadly ideological epidemic. The only hope for the health of the body politic, and for the health of Peru's contaminated history, is a swift excision to remove the offending Mayta, site of Bersani’s provocatively defined rectal grave. Mayta, and the abject sexuality he signposts, represent "a disposable constituency" (Bersani 204).

\footnotetext{
${ }^{11}$ Vargas Llosa's own 1981 account of this prison is contained in “Una visita a Lurigancho” (Contra viento 303-7).
} 


\section{The queer limits of Vargas Llosian liberalism}

Speaking of Vargas Llosa's 1993 autobiography, El pez en el agua, Ellis notes that a key to understanding the literary evolution of Vargas Llosa lies in his comparison between the (implicitly male) writer of fiction and the (assumed female) stripper. That is, "whereas the stripper ... exposes herself to an objectifying gaze, the male writer shields himself from scrutiny in order to avoid objectification altogether” (79). Vargas Llosa plays this shielding game by “cloak[ing] the autobiographical persona in what might be called the gender and racial drag of masculinity and whiteness,” which in El pez en el agua, at least, means that the author's identity core of white hetero-masculinity is counterpointed by, and made meaningful in opposition to, socalled "homosexual femininity” (80).

A similar process is at work in Historia de Mayta. By making the real Mayta responsible for disposing of the queer Mayta, the shadowy narrator appears to survive the novel untainted. Indeed, he alone of all the novel's characters is implied to be the only uncontaminated body in Peru. This construction is achieved because in his fictionalizing the narrator so insistently casts everything—nation, populace, history—beyond himself into an abject zone. Yet, as Kristeva has argued, such relations to the abject are fraught, tenuous, and always self-defeating. Thus, while it might seem that the narrator is "opposed” to the abject, "the jettisoned [abject] object” nonetheless “draws” the narratorial I “toward the place where meaning collapses” (1-2). In that place, rendered in Historia as moribund Peru, "the abject does not cease challenging its master" (2). In Vargas Llosa's novel, various indigenous, leftist, and sexual abjections fill the spaces created by the narrator's silences regarding his own ideological interests and identifications against multiple Others. However, in the end the clamoring of these “jettisoned objects” demands critical attention. The abundant representations of the abject ensure that neither the narrator, nor 
the Vargas Llosa author-function, nor the author, can guarantee that their fictional immunity from ideological self-interest will be recognized, endorsed, or applauded by the novel’s readers.

Indeed, by allowing what was once an empty signifier to signify so much, to characterize the queer Mayta as the pathogenic source and symptom of Peru's moribundity, and by removing that offending signifier at the tail-end of the novel, Vargas Llosa resorts to an unambiguous rearguard action in his fictive game of truth, lies and lives. He posits a quick cure for infection and degeneracy. Despite the novel’s identification of multiple abjections, Vargas Llosa's cure nonetheless overtly targets the queer. Thus, as with the discourses of AIDS that began to circulate in the world outside Vargas Llosa's novel during its writing, Historia de Mayta demands to be read, as I do here, as a fictional attempt to represent "male homosexuality as a stage doomed to extinction ... on the enormous scale of whole populations” (Sedgwick 128-29). And yet, while the queer Mayta may be cleansed from the narrative, the consequences of his narratorial presence are not so easily discounted. As a trope of subjective negativity, impossibility, and disposability, the queer Mayta in Historia is not alone in Vargas Llosa's novels. Many other characters have served the same function in works such as Conversación en la Catedral, La ciudad y los perros, La guerra del fin del mundo, Elogio de la madrastra, and Los cuadernos de don Rigoberto. However, as a template of Vargas Llosa's author-function since the early 1980s, Historia de Mayta stands out from this competition. The novel does not merely grate against a Liberal celebration of "tolerance and respect for others." By making the "recto supurando, gangrenado, cancerizado” of all who may share in Mayta's desires its central target, Historia de Mayta also lays bare the Vargas Llosa author-function's broader operations as a fabulist of queer cleansing.

\section{Works Cited}


Allatson, Paul. “'My Bones Shine in the Dark’: AIDS and Chicano Queer De-scription in the Work of Gil Cuadros.” Aztlán: A Journal of Chicano Studies 32.1 (Spring 2007): 23-52.

Arguedas, José María. Formación de una cultura indoamericana. 2a ed. México: Veintiuno, 1977.

Bersani, Leo. “Is the Rectum a Grave?” AIDS: Cultural Analysis, Cultural Activism. Ed. Douglas Crimp. Cambridge and London: MIT Press, 1988. 197-222.

Booker, M. Keith. Vargas Llosa among the Postmodernists. Gainesville: University Press of Florida, 1994.

Browitt, Jeff. Remembering Futures Past: National Failure in Gabriel García Márquez’s Cien años de soledad and Mario Vargas Llosa’s La guerra del fin del mundo. Unpublished PhD dissertation, Centre for Comparative Literature and Cultural Studies, Monash University, Melbourne Australia, 1999.

Caro, Olga. “Conceptos varguianos y sexualidad.” In Escritura y sexualidad en la literatura hispanoamericana: Coloquio internacional. Eds Alain Sicard and Fernando Moreno. Poitiers: Centre de Recherches Latino-Américaines, Université de Poitiers; Madrid: Fundamentos, 1990. 167-80.

Chrzanowski, Joseph. “Mario Vargas Llosa y la interpolaridad vida-ficción.” La historia en la literatura Iberoamericana. Eds. Raquel Chang-Rodríguez y Gabriella de Beer. New York: City University of New York Press, 1989. 317-25

Congrains Martín, Eduardo. No una, sino muchas muertes. Buenos Aires: Embajada Cultural Peruana, 1957.

Douglas, Mary. Purity and Danger: An Analysis of Concepts of Pollution and Taboo. London: Routledge and Kegan Paul, 1966.

Dunkerley, James. “Mario Vargas Llosa: Parables and Deceits.” Political Suicide in Latin America and Other Essays. London: Verso, 1992. 139-52.

Edelman, Lee. Homographesis: Essays in Gay Literary and Cultural Theory. New York: Routledge, 1994.

Ellis, Robert Richmond. They Dream Not of Angels but of Men: Homoeroticisim, Gender, and Race in Latin American Autobiography. Gainesville: University Press of Florida, 2002. Flores, Juan. Divided Borders: Essays on Puerto Rican Identity. Houston: Arte Público, 1993. Foucault, Michel. “What is an Author?” In Language, Counter-Memory, Practice: Selected 
Essays and Interviews. Eds Donald F. Bouchard. Trans. Donald F. Bouchard and Sherry Simon. Ithaca: Cornell University Press, 1977. 113-38.

Franco, Jean. The Modern Culture of Latin America: Society and the Artist. Harmondsworth: Penguin, 1970.

García Pinto, Magdalena. “Anatomía de la revolución en La guerra del fin del mundo e Historia de Mayta de Mario Vargas Llosa.” The Historical Novel in Latin America: A Symposium. Ed. Daniel Balderston. Gaithersburg: Ediciones Hispamérica, 1986. 159-71. Gilman, Sander L. "Plague in Germany, 1939/1989: Cultural Images of Race, Space and Disease.” Nationalisms and Sexualities. Eds. Andrew Parker et. al. New York: Routledge, 1992. $175-200$.

González Prada, Manuel. El tonel de Diógenes. México: Edición Tezontle, 1945.

Grandis, Rita de. “La problematica del conocimiento histórico en Historia de Mayta de M.

Vargas Llosa.” Revista de Crítica Literaria Latinoamericana 19 (1993): 375-82.

Guzmán, Jorge. “A Reading of Vargas Llosa’s The Real Life of Alejandro Mayta.” Latin

American Literary Review 15 (1987): 133-39.

Higgins, James. A History of Peruvian Literature. Liverpool: Francis Cairns, 1987.

Huston, Hollis. "Revolutionary Change in One Hundred Years of Solitude and The Real Life of Alejandro Mayta.” Latin American Literary Review 15 (1987): 105-20.

Kristeva, Julia. Powers of Horror: An Essay on Abjection. Trans. Leon S. Roudiez. New York: Columbia University Press, 1982.

Mariátegui, José Carlos. Siete ensayos de interpretación de la realidad peruana. 1928. 13a ed. Lima: Biblioteca Amauta, 1968.

Miller, D. A. The Novel and the Police. Berkeley: University of California Press, 1988.

Muñoz, Braulio. A Storyteller: Mario Vargas Llosa between Civilization and Barbarism. New York: Rowman \& Littlefield, 2000.

Newman, Kathleen. “Historical Knowledge in the Post-Boom Novel.” The Historical Novel in Latin America: A Symposium. Ed. Daniel Balderston. Gaithersburg: Ediciones Hispamérica, 1986. 209-20.

Pope, Randolph D. “Precauciones para la lectura de Conversación en la catedral.” Journal of Spanish Studies 6 (1978): 207-17.

Reisz de Rivarola, Susana. “La historia como ficción y la ficción como historia: Vargas Llosa y 
Mayta.” Nueva Revista de Filología Hispánica 35 (1987): 835-53.

Rowe, William. "Liberalism and Authority: The Case of Mario Vargas Llosa." On Edge: The Crisis of Contemporary Latin American Culture. Eds. George Yudice, Jean Franco and Juan Flores. Minneapolis: University of Minnesota Press, 1992. 45-64.

Salazar Bondy, Sebastián. Lima la horrible. Lima: Populibros, 1964.

Sedgwick, Eve Kosofsky. Epistemology of the Closet. Berkeley: University of California Press, 1990.

Sontag, Susan. Illness as Metaphor/AIDS and its Metaphors. London: Penguin, 1991.

Souza, Raymond D. La historia en la novela hispanoamericana moderna. Bogotá: Tercer Mundo, 1988.

Spitta, Silvia. Between Two Waters: Narratives of Transculturation in Latin America. Houston: Rice University Press, 1995.

Treichler, Paula A. “AIDS, Homophobia, and Biomedical Discourse: An Epidemic of Signification.” AIDS: Cultural Analysis, Cultural Activism. Ed. Douglas Crimp. Cambridge: MIT, 1988. 31-70.

Vargas Llosa, Mario. La ciudad y los perros. Barcelona: Seix Barral, 1962. “Confessions of a Liberal.” American Enterprise Institute for Public Policy Research. Lecture delivered on March 3 2005. Online, Available: htttp://www.aei.org/include/pub_print.asp?pubID=22053 (Accessed October 13, 2008). Contra viento y marea, I: (1962-1972). 1983. Barcelona: Seix Barral, 1986. Conversación en la catedral: I y II. Barcelona: Seix Barral, 1969. Los cuadernos de don Rigoberto. Madrid: Alfaguerra, 1997. Elogio de la madrastra. Barcelona: Tusquets, 1988. La guerra al fin de mundo. Barcelona: Seix Barral, 1981. Historia de Mayta. Barcelona: Seix Barral, 1984. El pez en el agua. Barcelona: Seix Barral, 1993. The Real Life of Alejandro Mayta. Trans. Alfred MacAdam. London: Faber \& Faber, 1986.

A Writer's Reality. New York: Syracuse University Press, 1991.

Williamson, Judith. "Every Virus Tells a Story: The Meanings of HIV and AIDS.” Taking Liberties: AIDS and Cultural Politics. Eds. Erica Carter and Simon Watney. London: 
Serpent's Tail, 1989. 69-80.

Zapata, Roger A. “Las trampas de la ficción en la Historia de Mayta.” La historia en la literatura iberoamericana. Eds. Raquel Chang-Rodríguez y Gabriella de Beer. New York: City University of New York Press, 1989. 189-97. 
VARGAS LLOSA AND

LATIN AMERICAN POLITICS

Edited by Juan E. De Castro and Nicholas Birns

\section{palgrave}

macmillan 
Where this book is discributed in the UK, Europe, and the rest of the world, this is by Palgrave Macmillan, a division of Macmillan Publishers Limited, registered in England, company number 785998, of Houndmills, Basingstoke, Hampshire RG21 6XS.

Palgrave Macmillan is the global academic imprint of the above companies and has companies and representarives throughout the world.

Palgrave( ${ }^{(}$and Macmillan@ are registered trademarks in the United States, the Unitce Kingdom, Europe and other countries.

ISBN: 978-0-230-10529-4

Library of Congress Cataloging-in-Publication Data

Vargas Llosi and Laxin American politics / edited by Juan E. De Castro and Nicholas Birns.

p. $\mathrm{cm}$.
Includes index.

ISBN 978-0-230-10529-4 (alk. paper)

1. Vargas Llosa, Mario, 1936—Criticism and interpretation. 2. Vargas Llosa, Mario, 1936-Political and social views. 3. Latin America-Polivics and governmenc. 1. Cascro Juan E. De, 1959- 11 Birns, Nichols.

PQ8498.32.A65Z945 2010

$863^{\prime} .64-\mathrm{dc} 22$

2010011095

Design by Scribe Inc.

First edition: October 2010

1098765432

Printed in the Unired Srates of America.

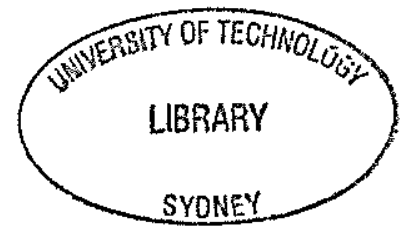

Acknowledgments

Timeline

Introduction

Juan E. De Castro and Nicholas Birns

I Mario Vargas Llosa and the Neoliberal Turn

$1 \mathrm{Mr}$. Vargas Llosa Goes to Washington Juan E. De Castro

2 The Wars of an Old-Fashioned (Neoliberal) Gentleman Fabiola Escárzaga

3 "Let's Make Owners and Entrepreneurs": Glimpses of Free Marketeers in Vargas Llosa's Novels Jean O'Bryan-Knight

II The Writings of the 1980 s and 1990 s

4 Appropriation in the Backlands: Is Mario Vargas Llosa at War with Euclides da Cunha? Nicholas Birns

5 Mario Vargas Llosa, the Fabulist of Queer Cleansing Paul Allatson

6 Going Native: Anti-indigenism in Vargas Llosa's The Storyteller and Death in the Andes Ignacio López-Calvo

7 The Recovered Childhood: Utopian Liberalism and Mercantilism of the Skin in A Fish in the Water Sergio R. Franco 
III Mario Vargas Llosa in the Twenty-First Century

8 Sex, Politics, and High Art: Vargas Llosa's Long Road to The Feast of the Goat Gene H. Bell-Villada

9 Humanism and Criticism: The Presence of French Culture in Vargas Llosa's Utopia

Roland Forgues

IV Mario Vargas Llosa, Man of Letters

10 Vargas Llosa's Self-Definition as "The Man Who Writes and Thinks"

Sabine Köllmann

11 Vargas Llosa and the History of Ideas: Avatars of a Dictionary Wilfrido $H$. Corral

Works Cited

Contributors

Index

\section{ACKNOWLEDGMENTS}

We want to thank our colleagues at Eugene Lang College, Professor Laura Frost and Dean Neil Gordon, for their encouragement and for creating an environment that promotes research and scholarly production.

Salmagundi and Revista de Estudios Hispánicos generously permitted the inclusion of revised versions of essays they had previously published.

Nicholas Birns thanks Larry Birns, his father, and Margaret Boe Birns, his mother, for their affection and support and for having introduced him to Latin America. Juan De Castro is grateful for the support of his wife, Magdalena, during the writing and editing of this book.

We both thank the colleagues who kindly contributed their essays. Without their enthusiasm, dedication, and patience, this book would not have been possible.

1. An early draft of Chapter 5, "Mario Vargas Llosa, the Fabulist of Quecr Cleansing," by Paul Allatson, was first published as "Historio de Mayta: A Fable of Queer Cleansing" in Revista de Estudios Hispanicos 32.3 (Oct. 98): 511-35. An early version of Chapter 8, "Sex, Politics, and High Art: Vargas Llosa's Long Road to The Feast of the Goat," by Gene H. Bell-Villada, was published as "The Inventions and Reinventions of Mario Vargas Llosa," in Salmagundi 153/154 (Winter 2007): 148-57. 
"This superb collection of essays brings together a series of lively and sometimes polemical perspectives on the political dimensions of Mario Vargas Llosa's writings. Indispensable reading for anyone seeking a better understanding of Vargas Llosa's intellectual trajectory."

- Maarten Van Delden, Professor of Latin American Literature, UCLA

Written from diverse perspectives, the eleven essays that make up Vargas Llosa and Latin American Politics portray the Peruvian novelist not only as one of the most celebrated writers of the last 50 years, but also as a central influence on the region's political evolution. Ever since his conversion to free market ideology in the 1980s, Mario Vargas Llosa has waged public battle against what he believes are the scourges of socialism and populism. This book studies the fiction and journalism of Vargas Llosa in the context of his political thought.

Juan E. De Castro teaches at Eugene Lang College, the New School for Liberal Arts. He is the author of Mestizo Nations: Culture, Race, and Conformity in Latin American Literature (2002) and The Spaces of Latin American Literature:Tradition, Globalization, and Cultural Production (2008).

Nicholas Birns teaches at Eugene Lang College, the New School for Liberal Arts, His book include Understanding Anthony Powell (2004), A Companion to Australian Literature Since 1900 (2007), and Theory After Theory: An Intellectual History of Literary Theory Since 1950 (2010).
Cover photo courtesy of Miami Dade College.

Cover design by Scribe, Inc.

palgrave macmillan

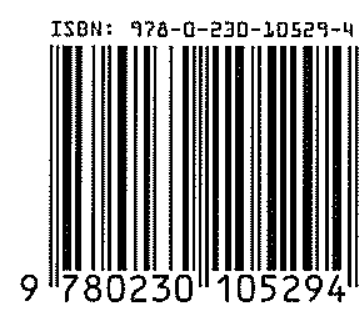

www.palgrave.com
UTS LIBRARY
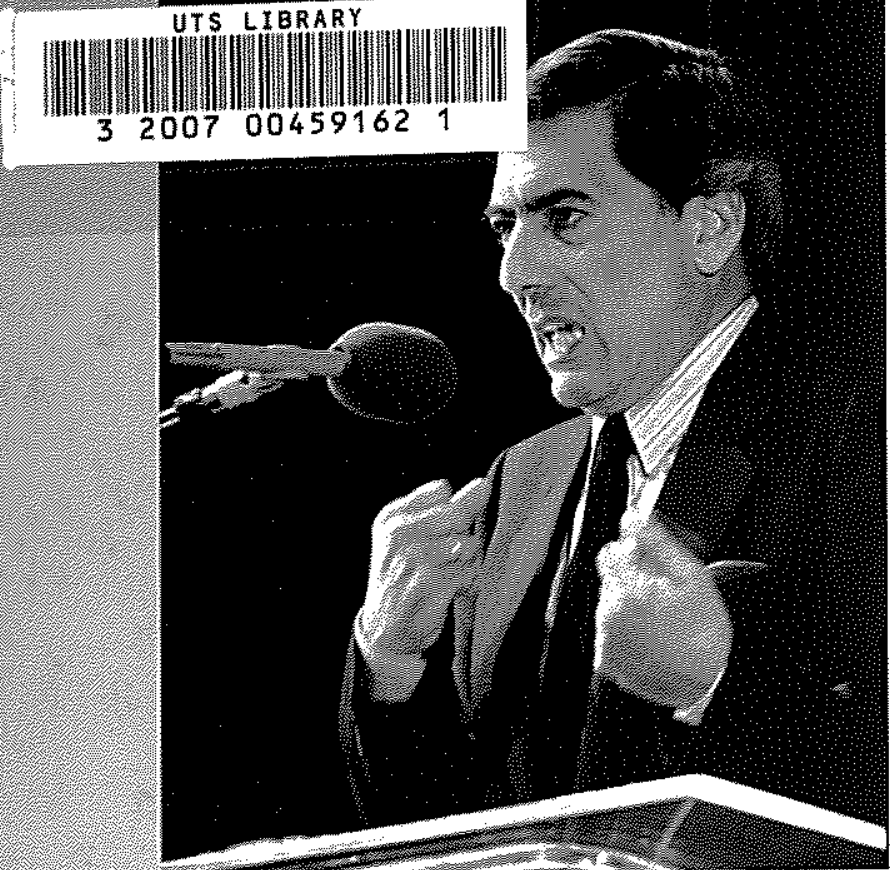

产

\section{Vargas Llosa and} Latin American Politics

Edited by

Juan E. De Castro and Nicholas Birns 